\title{
devaneios voltados para uma infância com o barro
}

\author{
beatran hinterholz ${ }^{1}$ \\ universidade federal do rio grande do sul, brasil \\ sandra richter ${ }^{2}$ \\ universidade de santa cruz do sul, brasil
}

\section{resumo}

O ensaio aborda uma experiência de escrita constituída no percurso de estudos e pesquisa acadêmica circunscritos pela relação entre educação, infância e fenomenologia da imaginação poética em Gaston Bachelard. Da sugestão bachelardiana de substituir diante do mundo a percepção pela admiração, para reter os valores daquilo que se percebe, emerge uma escrita tingida tanto pelos encontros com bebês, crianças pequenas e suas professoras na educação infantil quanto pelos devaneios da primeira autora a partir das imagens fotográficas das brincadeiras com o barro. Para descrever e refletir a complexidade dos devaneios voltados para uma experiência de infância, desde a admiração e a interpretação de imagens fotográficas, optamos pela fenomenologia bachelardiana da imaginação poética. Assumir a admiração como possibilidade de ultrapassar o percebido, como modo de reencontrar e prolongar - pela imaginação - as forças que estão no mundo, é transgredir uma escrita que explica e verifica para priorizar o movimento entre sonhar e pensar provocado pelos valores de uma infância que dinamizam reservas de entusiasmo que nos convidam a habitar e participar do mundo com outras palavras.

palavras-chave: devaneio; infância; bachelard; filosofia; educação.

\section{daydream on a childhood with the clay}

abstract

The essay addresses a writing experience constituted during a research project inspired by the relationship between education, childhood and Gaston Bachelard's poetic imagination phenomenology. From the bachelardian suggestion of replacing in face of the world the perception with admiration, to retain the values of what is perceived, emerges a writing dyed both by the encounters of babies, small children and teachers and by the rêveries of the first author from photographic records of children's play with clay. In order to describe and think the complexity of the rêveries possibles from a childhood experience, we opted for the bachelardian phenomenology of poetic imagination. To assume the admiration as a possibility to surpass the perceived, as a way to reencounter and extend - through imagination - the forces that are in the world, it's to transgress a writing that explains and verifies to highlight the movement between dreaming and thinking provoked by the values of a childhood that animate reserves of enthusiasm that invite us to inhabit and to take part in the world with another words.

keywords: rêverie; childhood; bachelard ; philosophy; education.

\footnotetext{
1 E-mail: beaholz30@yahoo.com.br

2 E-mail: srichter@unisc.br 


\section{ensoñaciones voltadas para una infancia con el barro}

resumen

El ensayo aborda una experiencia de escritura constituida en el curso de estudios e investigación académica en torno de la relación entre educación, infancia y fenomenología de la imaginación poética en Gaston Bachelard. Desde la sugerencia bachelardiana de sustituir ante el mundo la percepción por la admiración, para retener los valores de lo que se percibe, emerge una escritura teñida tanto por los encuentros con bebés, niños pequeños y sus profesoras en la educación infantil cuanto por las ensoñaciónes de la primera autora a partir de imágenes fotográficas de juegos con el barro. Para describir y reflexionar la complejidad de las ensoñaciones que tienden a una experiencia de infancia, desde la admiración y la interpretación de imágenes fotográficas, optamos por la fenomenología bachelardiana de la imaginación poética. Asumir la admiración como posibilidad de transponer lo percibido, como modo de reencontrar y prolongar - por la imaginación - las fuerzas que están en lo mundo, es transgredir una escritura que explica y verifica para priorizar el movimiento entre soñar y pensar provocados por los valores de una infancia que dinamizan reservas de entusiasmo que nos invitan a habitar y participar del mundo con otras palabras.

palabras clave: ensoñación; infancia; bachelard; filosofía; educación. 
devaneios voltados para uma infância com o barro

\section{introdução}

Tempos caminhados com palavras e imagens, perto do chão com as folhas que cantam, gesto tocando a vida que "esconde-se por trás das palavras para mostrar-se" (BARROS, 2013, p.13). Escondo-me, mostro-me. Escondo-me atrás das palavras de Carlos Skliar (2015) para conhecer, amar e falar...

Se realmente queres conhecer como se anda de bicicleta, sobe nela, cai, arranha as pernas, contradiz as brisas de setembro. Se queres amar, não tente desistir diante da impetuosidade da primeira leve ferida. Se vais falar da terra, afunda-te na fronteira mais tempestuosa e distante. Se vais falar de outro homem, escuta-o (SKLIAR, 2015, p. 143).

Antes de expor uma escrita nas próximas linhas escutei as imagens. Escrita tingida de devaneios ${ }^{3}$ que forjaram imagens e conceitos. Aprendi a andar de bicicleta. Amei. Afundei na terra. Contudo, falar de outro humano é difícil, quase um mistério; preciso antes escutá-lo. Se cobiçamos estudar a imaginação poética para falar do encontro com o barro torna-se importante fechar os olhos e escutá-lo. Para Gaston Bachelard (1993, p. 100), “sempre haverá mais coisas num cofre fechado do que num cofre aberto. A verificação faz as imagens morrerem. Imaginar será sempre maior que viver".

Na concepção fenomenológica de Bachelard (1990), o vivido conserva a marca do efêmero se não for revivido pela imaginação poética, se não for amplificado ao incorporar o vivido imaginado, se não passar do fato ao valor. Viver, nessa acepção, não tem centro, pois imaginar envolve ensaiar e instaurar muitos modos ou tempos de viver ${ }^{4}$. Basta emergir uma imagem, uma valoração do vivido, para nos tornarmos "uma colmeia de seres, [...] atravessados por redemoinhos" (BACHELARD, 1990, p. 41). Porém, a realidade material ou solidez do barro, sua

\footnotetext{
${ }^{3}$ Em A poética do devaneio (2009), Bachelard distingue devaneio e sonho. Se o sonho dorme, o devaneio permanece acordado - vigilante. Assim, o sonho pode ser contado, o devaneio não. Para compartilhá-lo é preciso escrevê-lo, desenhá-lo, cantá-lo; arriscamos dizer que também é preciso ser modelado pela mão artesã.

4 "Em que periferia se anima a vida? E, como ela se anima sobretudo ao exprimir-se, rumo a que imagens, em que poemas, o ser encontra sua verdadeira vida, a vida excessiva? O ser humano nunca é fixo, ele nunca está lá, jamais vivendo no tempo onde os outros o veem viver, onde ele mesmo diz aos outros viver" (BACHELARD, 1990, p. 41).
} 
evidência à visão, torna mais laborioso e sutil os devaneios emergentes da intimidade do encontro com a materialidade terrestre. Para superar esse obstáculo, Bachelard (2013) rejeita a percepção de imagens como determinante dos processos de imaginação ao contrapor "bem ver" ao "bem sonhar". Contra o consenso realista de que "vemos as coisas primeiro, imaginamo-las depois; combinamos, pela imaginação, fragmentos do real percebido" (BACHELARD, 2013, p. 2), afirma a anterioridade das imagens (ou a valoração do vivido) em relação à percepção. Sua concepção de imaginação poética como "aventura da percepção" (BACHELARD, 2013, p. 3) nega o vício da ocularidade para destacar que as imagens são mais fortes que as ideias e as experiências reais.

Fechar os olhos para realizar a escuta dos devaneios voltados para o vivido com o barro implicou descartar verificações e análises de ideias. Foi preciso escrever e transgredir a escrita, pensar e devanear com as palavras e os sentidos. Escrita exigente, escrita que escutou devaneios voltados para uma infância. Escutei em mim as reservas de entusiasmo encarnadas e as aproximei do pensamento de Bachelard.

Durante o estudo desenvolvido na pesquisa ${ }^{5}$ o que me angustiou ou "bateu", nas palavras do poeta Manoel de Barros "Bateu bateu, não bateu, esquece", foram as imagens das crianças brincando com o barro na escola com as quais convivo e também na qual a pesquisa foi realizada. No início, a inquietação que emergiu foi: O que em mim estas imagens remetem? Não tinha ainda ponderado a possibilidade das imagens me olharem ao provocarem recordações da minha infância.

Assim, nossa estratégia teórico-metodológica para estudar e nos aproximarmos da imaginação poética ${ }^{6}$ no cotidiano da educação infantil foi permanecer com o grupo das crianças bem pequenas e suas professoras alguns momentos de modo intencional e planejado com as professoras, em especial quando

\footnotetext{
5 Estudo realizado na dissertação de mestrado "Ninho Bachelardiano: imaginação poética, mundanidade e educação de crianças pequenas na creche" (2016), no grupo de pesquisa Estudos Poéticos: Educação, Linguagem e Infâncias, Programa de Pós-Graduação em Educação da Universidade de Santa Cruz do Sul - UNISC.

${ }^{6}$ Bachelard em sua obra não conceitua ou explica o fenômeno da imaginação poética mas no decorrer da escrita nos conduz à descrição de atributos que nos aproximam aos modos como pode acontecer. Uma opção hermenêutica mais ocupada com a caracterização da função imaginante que sua definição. A resposta bachelardiana à pergunta essencialista "que é a imaginação?" seria, segundo Romero (2002, p. 16), "não sei o que é, mas é criadora, material, dinâmica, cósmica ...".
} 
as crianças estavam brincando com a argila, a água, o barro ou a terra. Outros momentos foram acontecendo tanto no tempo de estar e conviver na escola de educação infantil quanto no tempo da escrita. A dissertação narrou com as imagens fotográficas ${ }^{7}$ o vivido da docência com as crianças pequenas e com um modo de escutar a infância a partir das fenomenologias de Gaston Bachelard e de Hannah Arendt ${ }^{8}$.

A opção metodológica emergiu da admiração pela beleza sensual das fotografias das cenas das crianças pequenas lidando e brincando com o barro - e não o ato de ter com elas vivido esse mesmo momento. O encantamento pelo estudo surgiu da experiência de ser provocada pelos meus devaneios voltados para os encontros com o barro quando criança. "Num devaneio, uma vez que nos lembramos, o passado é designado como valor de imagem. A imaginação matiza desde a origem os quadros que gostará de rever. Para ir aos arquivos da memória, importa reencontrar, para além dos fatos, valores" (BACHELARD, 2009, p.99). A imagem imaginada ${ }^{9}$ como valoração do vivido permite ao filósofo negar a imaginação poética como eco de um passado. Em sua atualidade de valorar no ato mesmo de realizar algo (escrever, cantar, pintar, silenciar, dançar, ler), torna inerte tudo o que deriva do passado e, portanto, a memória tem que ser re-imaginada, ou seja, re-contada ou dramatizada no instante realizador.

O devaneio em direção ao nosso passado, pela imaginação poética e experiência de linguagem, nos abre o mundo da mesma maneira que o devaneio da criança, aqueles dos primeiros instantes de "habitar" um mundo. Abordar a

\footnotetext{
${ }^{7}$ Algumas das imagens fotográficas foram produzidas pela primeira autora e outras pelas próprias professoras em momentos distintos do cotidiano. Na escola, são produzidas muitas fotos das crianças para compor o registro e a documentação pedagógica de cada uma e do grupo.

8 Optamos, no espaço e tempo deste ensaio, por nos deter na interlocução com a fenomenologia da imaginação poética de Gaston Bachelard, mas também sustentam essa escrita as concepções de natalidade e mundanidade que compreendemos a partir de Hannah Arendt (2014; 2008). Ao referirmos a fenomenologia de Bachelard estamos remetendo ao conjunto de suas publicações (19281961). Para além da usual divisão de sua obra em diurno (ciência) e noturno (poesia), nosso grupo de pesquisa o considera um estudioso que retificou seu pensamento não linearmente ao transgredir as próprias ideias. Para ler sua obra, não é necessário início, meio e fim. Demanda esforço de leitura, devaneios e metamorfose.

9 Em Bachelard (2013, p. 3), o caráter fundamental da imaginação poética está na dinâmica das imagens imaginadas, anteriores às imagens percebidas. Aqui, os fatos não explicam os valores.
} 
infância a partir da perspectiva aberta pelo devaneio é considerar que o passado não é estável, alcançável, "ele não acode à memória nem com os mesmos traços, nem com a mesma luz" (BACHELARD, 2009, p.99). Nesse sentido, "toda nossa infância está por ser reimaginada" (BACHELARD, 2009, p.94).

Cabe destacar que Bachelard não coloca a lembrança sob a redenção de um fantasma narcísico de absoluta soberania, nem a compreende como a expressão de uma subjetividade que coincide com ela mesma. Aqui, ele se distancia de uma visão reduzida em causa e efeito, para devolver ao passado sua dimensão histórica. Para tanto, compreende a imaginação como fenômeno de linguagem e, portanto, a memória como "sempre já" na linguagem.

Se o devaneio em direção ao passado rompe os tempos encadeados, permanece necessário a fusão entre as dimensões do real e do ficcional na ação sonhadora para que nossas lembranças de infância sejam ao mesmo tempo mais que "fatos" e menos que "alucinações", reportando ao passado na simultaneidade que convocam o devir. Não regemos nosso passado, o interpretamos e, nessa ação linguageira, nos "apropriamos" de nossas narrativas. Guimarães Rosa (2001) acolhe Bachelard ao escrever em Grande Sertão: Veredas que ao narrar o que vale são outras coisas e, por isso, Riobaldo conta sua história "desemendando" o tempo.

A lembrança da vida da gente se guarda em trechos diversos, cada um com
seu signo e sentimento, uns com os outros acho que nem não misturam.
Contar seguido, alinhavado, só mesmo sendo as coisas de rasa
importância. De cada vivimento que eu real tive, de alegria forte ou pesar,
cada vez daquela hoje vejo que era como se fosse diferente pessoa.
Sucedido desgovernado. Assim eu acho, assim é que eu conto (ROSA,
2001, p.114).

Vocês são bondosas e bondosos em escutar. No "vivimento", uma imagem imaginada remete a outras imagens não sendo passível de ser explicada pelo conceito já que não é uma representação a decompor, a analisar, mas a animar e a transformar em devaneio. O devaneio continua porque pode ativar arborescências de imagens pelas virtualidades de sentidos permanecidos em potência na palavra, promovendo abertura ao porvir da linguagem. É o dinamismo criador da imaginação tornando-se linguagem. Aqui, Bachelard nega o vínculo da imaginação poética com a percepção para afirmá-la como acontecimento de linguagem. Assim, 
o ato mesmo de escrever foi compondo um ver mais além do que as figurações das fotografias mostravam, dinamizando imagens e atualizando sensações capazes de afastarem visões e pensamentos habituais como um grande pássaro alçando voo do seu ninho.

Neste ensaio propomos considerar a relevância educacional de acolher com Bachelard um pensamento que se faz no processo da escritura, como persistente exercício de desconceitualização quando pretendemos aproximar infância e imaginação poética. Nesse sentido, a opção pela escrita fenomenologicamente orientada pelos devaneios voltados para uma infância com o barro, a terra e a água, configurou importante opção para enfrentar um tema que exige, antes de explicações, empatia ao corpo que sente, que não é corpo em si, mas corpo em situação (MERLEAU-PONTY, 1991). Ou seja, em sua existência mundana.

Tanto o tema da infância quanto o da educação e imaginação poética dizem respeito à temporalidade dos começos. A experiência de começar é uma das mais densas de sentido na convivência mundana e, por isso, a intenção que orienta este ensaio é a de convidar o leitor a acolher a complexidade que é iniciar o gesto de fazer algo aparecer ao olhar - de aprender a trazer ao visível uma narrativa gestual no encontro do corpo com a materialidade do barro- a partir da existência da criança e não a partir de prévias explicações sobre ela ou sobre a ação de modelar. Nesse sentido, modelar não traduz mero "mexer" o barro com as mãos, antes traduz o envolvimento do corpo inteiro no movimento vital de dar forma, agregar à massa um pensamento, uma vontade, um sentido, uma ação operativa, portanto transformadora. Um convite a pensar de outro modo as primeiras experiências de provocação do barro que convoca o corpo a amassar, cortar, enrolar, colar, esticar, beliscar, emendar, alisar. A ação tátil, sensual, dinâmica, ao seguir rumos para explorar e configurar o barro, expande quem a realiza permitindo reconhecer sua energia poética de transformação de sentidos. Um convite a acolher, desde a 
filosofia, a questão - ou o enigma - da imaginação poética como acontecimento linguageiro ${ }^{10}$.

Uma escrita em ato que emerge da memória do encontro com as crianças, das imagens fotográficas das crianças brincando com o barro, as quais provocam antes admiração e devaneios voltados à infância vivida da primeira autora. Na abordagem bachelardiana da imaginação poética, ao escrever "sobre as lembranças da infância, o poeta fala da importância vital da obrigação de escrever. Na lenta escritura, as lembranças da infância se acalmam, respiram. A paz da vida da infância recompensa o escritor" (BACHELARD, 2009, p.129). Escrita que tenta nas próximas linhas permanecer no limiar dos sentidos que emergem das lembranças da infância. Os devaneios voltados para uma infância, a partir das imagens fotográficas das crianças, atualiza em quem escreve o pertencimento à argila, à experiência de acolhimento do corpo pela terra ao nela mergulhar com a água e fazer o que o barro quer (LEMINSKI, 1983).

\section{horas sem relógio ainda estão em nós: barro}

A única prova admissível da existência da água, a mais persuasiva e mais intimamente correta, afirma Bachelard (2009), é a sede. Estou com sede, ligo-me ao mundo como brincante na água que corre pelos devaneios voltados para minha infância, por um estreito caminho, vou junto mudando sua cor, seu modo de correr. Encontro um lugar para ficar e permaneço. Tudo começa a se transformar, o que era água e chão, vira barro comigo.

Modelagem! Sonho de infância, sonho que nos leva de volta a nossa infância! Foi dito frequentemente que a criança reunia todas as possibilidades. Crianças, éramos pintor, modelador, botânico, escultor, arquiteto, caçador, explorador. E o que aconteceu com tudo isso? (BACHELARD, 2013, p.76).

Na possibilidade de reunir os sonhos de infância, a água com tudo isso que aconteceu, permanece nos meus devaneios como força que encanta pela

\footnotetext{
${ }^{10}$ Termo utilizado por Merleau-Ponty (1991, p.94) para afirmar o corpo como linguagem. Concepção que rompe com a clássica descrição da percepção como "representação" objetiva de um mundo dado à consciência subjetiva. Há uma significação "linguageira" da linguagem que não se prende ao "penso", mas ao "posso" que diz respeito a ser próprio do gesto humano inaugurar sentidos, realizando uma experiência e sendo essa própria experiência, isto é, agindo no mundo
} 
sensualidade dos movimentos, pelo turbilhão de pensamentos que nos acontecem. Bachelard (1998, p.9) recorda: "não posso sentar perto de um riacho sem cair num devaneio profundo, a agua anônima sabe de todos os segredos. A mesma lembrança sai de todas as fontes". Devaneios intensos, devaneios de nossa fonte, de nossa infância. A água para os devaneios é brincante, sem rumo, é aquela que corre, que transforma, que modifica a matéria.

No barro temos unido os dois agentes: Terra e Água. As águas simbolizam
as energias latentes, as virtualidades. Ele regenera, fertiliza e multiplica as
potencialidades da Terra. "As águas simbolizam o reservatório de todas as
possibilidades de existência elas precedem toda a forma e suportam toda
a criação" (Mircea Eliade). É justamente a água que transforma a rocha em
argila e a argila em barro, dando-lhe infinitas possibilidades de receber
uma nova ordem (NAKANO, 1989, p.81).

Outra ordem, outra possibilidade de reinventar a terra, a argila, o que conduz decididamente a terra às metamorfoses, que consistem e relutam em se decompor, mas é a água, com ou sem a ajuda da mão, que a faz transformar. A água rompe barreiras, mas, se surgir a mão, ela caminha e delineia um caminho junto, transforma a matéria e também já não é mais só a água, já é um barro, e “o barro toma a forma que você quiser, você nem sabe estar fazendo apenas o que o barro quer" (LEMINSKI, 1983, p.90).

Com a chuva de verão, o barro quer, o barro torna-se maior, mais intenso e quente; na chuva de inverno, se contrai, torna-se menor e frio. Brinco, invento, sinto o mundo no encontro entre meu corpo, a terra e a água. Precisei tempo para entender que foi na intensidade desse encontro que tudo começou. Não sei bem se tudo, mas a inquietação que mobilizou o estudo da imaginação poética teve um instigante começo, uma bela admiração, um devaneio voltado para minha infância. Infância que habita em mim, pois "há devaneios tão profundos, devaneios que nos ajudam a descer tão profundamente em nós mesmos que nos desembaraçam da nossa história" (BACHELARD, 2009, p.93). Caminhando muitas vezes com a chuva e outras vezes depois da chuva nos córregos perto de casa, debaixo das árvores, fazendo barro com os pés, insistindo com a água e a terra, formando outra materialidade. Quando o barro não estava dado, era feito sem a chuva, com terra seca e água, e muitas vezes se transformava em alimento. 
É na mistura da terra com a água que o barro surge. Nos meus devaneios, os odores da terra molhada pela chuva na infância permanecem em mim. Recordo, como pertencimento vital, uma lembrança de cheiros da terra que são para Bachelard testemunhos da nossa composição com o mundo.

Essas lembranças dos odores de passado, nós as reencontramos fechando os olhos. Fechamos os olhos outrora para saborear-lhes a profundeza. Fechamos os olhos, e assim imediatamente nos pusemos a sonhar. E ao sonhar, ao sonhar simplesmente, num devaneio sereno, vamos reencontrálas. No passado como no presente, um odor amado constitui o centro de uma intimidade. Há memórias que são fiéis a essa intimidade (BACHELARD, 2009, p.132).

Nos cheiros que impregnam as estações da infância, reencontro e recordo o cheiro do barro, bem diferente do cheiro da terra seca. Juntos, terra e água, formam outra materialidade, que se faz com o meu corpo. Com Bachelard (2009, p.204), vou entendendo que "a massa que se modela infunde um doce devaneio nos meus dedos", devaneios que sentem, que atualizam sensações. Sinto uma poça de água, me aproximo com os pés e até com as mãos. Nessa junção entre terra, água e corpo, o barro se manifesta e se expressa com a mão modeladora.

São muitos os obstáculos ao estudarmos os devaneios a partir do encontro entre materialidade terrestre e infâncias. Mas, o grande “obstáculo pedagógico" a enfrentar no campo da educação de crianças é o longo debate em torno da tese realista quase imbatível de ser a percepção determinante dos processos imagéticos. É justamente no estudo da matéria terra - o qual é mais desfavorável por sua presença aos olhos e ao esforço transformador das mãos - que encontramos, com Bachelard, o caráter formativo ${ }^{11}$ fundamental da imaginação poética a partir do estudo das forças oníricas que engendram a dinâmica das imagens imaginadas, anteriores à percepção. Por mais que a terra se mostre aos olhos, a mão rompe com o que manipula na simultaneidade que mantém a forma da terra. Neste instante de sensualidade, de devaneio, nos colocamos na vontade de olhar para o interior da

\footnotetext{
${ }^{11}$ No pensamento educacional de Bachelard, formação científica ou formação poética comportam sempre duas faces: uma objetiva na qual se efetua a criação de um mundo e uma subjetiva na qual se opera um trabalho sobre si (FABRE, 1995), pois "se o objeto me instrui, ele me modifica" (BACHELARD, 1996, p.305). A ideia bachelardiana de formação emerge então da indissociabilidade entre o esforço da conquista do mundo e o esforço da conquista de si (RICHTER, 2005). Esforço que exige tempos lentos, pois "a conquista é lenta. É a derrota que é breve" (BACHELARD, 2013, p. 27, nota 7).
} 
terra, na sua profundidade de revelação de sentidos, que é do humano, o mais íntimo. Uma presença no gesto. Esse instante exige de mim outra escrita, escrita amassada pelos devaneios voltados para uma infância que manipula o barro. Paro de escrever... "essas horas sem relógio ainda estão em nós" (BACHELARD, 2009, p.125). Como continuar a escrever essa presença no mundo, essa atualização dos gestos da infância no sangue velho? Estou só ao escrever. Só eu posso fazer essa escrita que me é exigente em todos os aspectos, pois diz respeito aos meus devaneios. Uma infância reanimada. Uma infância narrada, revivida!

\section{uma infância habita em nós}

Reviver os tempos primais da vida é considerar a possibilidade de termos sido muitos na vida ensaiada, na nossa vida primeira. "Somente pela narração dos outros é que conhecemos a nossa unidade. No fio de nossa história contada pelos outros, acabamos, ano após ano, por parecer-nos com nós mesmos" (Bachelard, 2009, p. 93). Estas impressões no mundo da vida ensaiada são constituídas no corpo, no fazer, e não nas ideias. Bachelard (2009), ao reiterar que a nossa infância pode ser reimaginada, reencontrada nos devaneios voltados para as solidões da infância, reconhece a permanência em nós de um núcleo de infância, vivo, fora da história, narrada nos instantes da existência poética. Este reconhecimento pode ser narrado porque na infância conhecemos uma existência sem limites, um devaneio sem medida, sem fronteiras, "um devaneio de alçar voo" (BACHELARD, 2009, p.94). No excesso reencontramos um gesto de infância, imagens da infância, manifestações de uma infância permanente. E de que modo o gesto de uma infância potencial habita em nós? Como reencontrá-la? Bachelard (2009, p.95) declara que "vamos reencontrá-la nos nossos devaneios, mais ainda que na sua realidade, nós a revivemos em suas possibilidades. Sonhamos tudo o que ela poderia ter sido, sonhamos no limite da história e da lenda".

O devaneio no limite da história e da lenda, reimaginado, permanece como memória do corpo que fomos. Corpo capaz, nas palavras de Serres (2004, p.139), “de todas as metamorfoses possíveis; se ele não as executa de maneira perfeita, ele sabe, pelo menos, simulá-las ou imitá-las". A liberdade, as alegrias e os sonhos 
emergem também dos devaneios voltados para nossa infância e mostram-se nas grandezas de nossas imagens, valores infinitamente mais intensos de imensidão no mundo. No devaneio habitamos nosso mundo de imagens primeiras, já que "as raízes da grandeza do mundo mergulham numa infância" (BACHELARD, 2009, p.97). As imagens retiradas do mergulho na infância não são verdadeiras lembranças, o que foi não é estável. Os valores da intimidade não são esquecidos, mas também não têm a mesma memória. Assim, "somente quando a alma e o espírito estão unidos num devaneio pelo devaneio é que nos beneficiamos da união da imaginação e da memória" (BACHELARD, 2009, p.99). Para o filósofo, o passado rememorado não é percepção. No devaneio, quando lembramos o passado, emerge o valor das imagens, e para revivê-lo é preciso sonhar na paz de um grande repouso e na alegria. Os poetas, aqueles que nos seduzem, dizem que os nossos devaneios de criança valem a pena ser recomeçados. Galeano, através de Helena, nos seduz ao convite de buscar palavras.

Na casa das palavras, sonhou Helena Villagra, chegavam os poetas. As palavras, guardadas em velhos frascos de cristal, esperavam pelos poetas e se ofereciam, loucas de vontade de ser escolhidas: elas rogavam aos poetas que as escolhessem, as cheirassem, as tocassem, as provassem. Os poetas abriam os frascos, provavam palavras com o dedo e então lambiam os lábios ou fechavam a cara. Os poetas andavam em busca de palavras que não conheciam, e também buscavam palavras que conheciam e tinham perdido (GALEANO, 2007, p.19).

Na casa das palavras, como raízes das grandezas dos devaneios profundos da nossa infância, revivemos ao buscarmos palavras que já conhecemos e perdemos. Buscamos também recordar nossa infância e "recordar: do latim re-cordis, é voltar a passar pelo coração" (GALEANO, 2007, p.11), pelas palpitações, pelo corpo, pela vida que está louca para ser escolhida e reimaginada, pois não é datada e nem tem um fio condutor. O que lembramos da nossa solidão cósmica, que é para Bachelard (2009) o que nos une ao mundo, permanece em nós como núcleo de infância. São nossas reservas de entusiasmo, aquilo que une imaginação e memória, nos faz

sob a inspiração do mundo, um ser para o mundo. Eis o ser da infância cósmica. Os homens passam, o cosmos permanece, um cosmos sempre primeiro, um cosmos que os maiores espetáculos do mundo não apagarão em todo o decorrer da vida. A cosmicidade de nossa infância reside em nós. Ela reaparece em nossos devaneios solitários (BACHELARD, 2009, p. 103).

Uma infância potencial reside em nós. Aparecerá para além da nossa história 
datada como o que permaneceu da nossa mundanidade, como seres para o mundo e no mundo. Ao reaparecer a infância nos nossos devaneios solitários, recordamos a intimidade do mundo na infância habitada que busca vidas que não aconteceram, que foram imaginadas, mas que podem ser narradas a partir de nossas reservas de entusiasmos. "Na solidão, basta que uma massa seja oferecida aos nossos dedos para que nos ponhamos a sonhar" (BACHELARD, 2009, p.162).

Reservas de entusiasmo habitam em mim e permitem devanear, narrar. $\mathrm{Na}$ massa, no barro compartilhado com as crianças, na intimidade cósmica ao olhar imagens fotográficas de cenas das crianças brincando com o barro. Não o ato de ter com elas vivido esse mesmo momento, mas contraditoriamente "esse encontro foi vivido, vivido na distância da vida que pertence a um outro tempo. Não se trata de experimentá-lo hoje" (BACHELARD, 2009, p.134), mas sim viver o encantamento com o pertencimento a outro tempo, com a experiência de ser provocada pelos devaneios voltados para os meus primeiros encontros com o barro. Valores que evidenciam, dinamizam sensações e imagens capazes de afastarem visões e pensamentos habituais, matizando e reencontrando quadros que substituem a percepção visual pela admiração do mundo que mobiliza, que compartilha os valores de um estado de infância, uma estação de minha infância. Para Bachelard (2009, p.111) “A lembrança pura não tem data. Tem uma estação. É a estação que constitui a marca fundamental das lembranças. Que sol ou que vento fazia neste dia memorável?".

As imagens do sol, do vento, da chuva, do barro tornam-se tensas e memoráveis e, nas palavras de Bachelard, engrandecidas, permitindo viver o passado reimaginado, o meu passado, como recordação, que volta a passar pelo coração como lembrança da história contada pelos outros. Assim, as "lembranças tornam-se então grandes imagens, imagens engrandecidas, engrandecedoras" (BACHELARD, 2009, p.112). Estações que permanecem além da história. Uma corporeidade constituída no instante, no encontro do corpo com a terra capaz de provocar devaneios tensos, íntimos e de admiração. Devaneios que emanam de outrora e dos quais podemos dizer: Sim, sou eu revivendo - eu imaginando. Na fenomenologia bachelardiana, 
para a memória importa a valoração do vivido e não o factual ou a narração de uma história, pois "há devaneios tão profundos, devaneios que nos ajudam a descer tão profundamente em nós mesmos que nos desembaraçam da nossa história" (BACHELARD, 2009, p. 93). Permanece em nós um núcleo de infância "que emana de tantas fontes que seria tão inútil traçar-lhe a geografia quanto escrever-lhe a história". Podemos em nós realizar múltiplos nascimentos porque "as estações da lembrança permanecem fiéis às cores da primeira vez" (BACHELARD, 2009, p. 112).

Os benefícios do "mundo da primeira vez" (BACHELARD, 2009, p. 112) vão além da história, permanecem e tornam-se devaneio pela admiração promovida pelas imagens das crianças brincando com o barro. Valores de imagens primeiras transformados em devaneios ligados à infância. Bachelard (2009, p. 119) designa como acordo poético as imagens primais que ligam o humano ao mundano para demonstrar que "a infância permanece em nós como um princípio de vida profunda, de vida sempre relacionada à possibilidade de recomeçar. Tudo o que começa em nós na nitidez de um começo é uma loucura da vida". A infância permanece em nós como acordo poético que nos liga ao mundo quando revivificados por entusiasmos que duram em nós, nos fazendo confiar no mundo para tomar a iniciativa de retomá-los. Assim, os devaneios voltados para a infância, como possibilidade de recomeço, estabelecem um acordo poético ao serem revivificados como "reservas de entusiasmo que nos ajudam a acreditar no mundo, a amar o mundo, a criar o nosso mundo" (BACHELARD, 2009, p.119). Reservas de entusiasmo que promovem abertura para o mundo, um convite a habitar o mundo.

\section{infância como fonte de recomeços}

Uma infância como vida primeira tece nossas vidas, seja na memória seja na imaginação. Permanece em nós como foco de vida pelas reservas de entusiasmo que emergem das imagens primeiras, das estações da lembrança abastecidas por acontecimentos excepcionais que encontram ressonâncias em nós por viverem conosco um outro tempo. Bachelard (2009, p. 130) nos convoca pensar que a experiência da infância "não é uma coisa que morre em nós e seca uma vez, cumprido seu ciclo". Não é lembrança, permanece nos constituindo. O filósofo 
alerta "ai de quem não pode se lembrar de sua infância, reabsorvê-la em si mesmo, como um corpo, um sangue novo no sangue velho: está morto desde que ela o deixou" (BACHELARD, 2009, p. 130).

A infância, por não morrer nem secar, é sempre sangue novo no velho, é a soma das insignificâncias do humano que permanecem no devaneio solitário, quando estávamos sozinhos para estar e pensar no mundo, "livres para ver o pôrdo-sol, a fumaça a subir de um teto, todos esses grandes fenômenos que enxergamos mal quando não estamos sozinhos para olhar" (BACHELARD, 2009, p.122). Nossa solidão, como saber compartilhado no mundo, forja a produção de sentidos nos encontros e desencontros conosco mesmos. Procuramos outros modos de viver e de aprender com a solidão no mundo. A criança, ainda com mais vigor, se contrapõe à cronologia para entregar-se a uma estação, uma intensidade dos instantes que mergulha nos seus devaneios, na sua imaginação. E, nessa entrega, permite se perder profundamente na vibração da vida, no mistério de existir na solidão e com os outros.

Consideramos importante intencionalidade educacional a de viver na escola de educação infantil espaços e tempos nos quais a criança tenha direito ao devaneio, de constituir suas solidões como reservas de entusiasmos pelas suas primeiras experiências de e no mundo. Cogitamos então que possamos favorecer encontros de experiências e acontecimentos com as materialidades, pois a criança, na sua inquietação, sustenta uma coragem invencível, que conduz o adulto simultaneamente a mergulhar em sua infância, num esforço de deixar-se conduzir a um estado de infância, pois

Não podemos amar a água, amar o fogo, amar a árvore, sem colocar neles um amor, uma amizade que remonta a nossa infância. Amamo-las como infância. Todas essas belezas do mundo, quando as amamos agora no canto dos poetas, nós a amamos numa infância redescoberta, numa infância reanimada a partir dessa infância que está latente em cada um de nós (BACHELARD, 2009, p. 121).

Redescobrir a infância latente em cada um de nós é se dispor a reconhecer as primeiras felicidades, os cheiros, o detalhe imenso do mundo, o regozijo das primeiras alegrias. "O mundo regozijava-se para festejar o pão quente" (BACHELARD, 2009, p.137). Festejar o cheiro do pão quente! Amamos uma infância 
que é latente em nós, no nosso quarto de lembranças, que é o nosso corpo. Serres (2004, p.76) dirá que o corpo lembra e que "nossa primeira base cognitiva reside nas recordações encarnadas, pois o inconsciente é o nosso corpo [...] O corpo não recebe ajuda de qualquer memória externa, ele o faz por si só, [...]". O corpo sabe fazer e recordar. As lembranças dos odores, gestos, sensações, olhares e respiração permanecem em nós, encontram-se na nossa memória que pode respirar o passado. Cheirar, escutar, sentir, sonhar a chuva! Infância latente em mim, em ti, como valor das imagens felizes, como desejo de infância no ato de admiração com o mundo e comigo. Admiração que emerge do devaneio da infância à velhice, que produz realidade ao ser vivido como valor de co-existência no encontro entre corpo e mundo.

Por não serem dinâmicas livres nem naturais, aprendemos com ardor no nosso mundo primal a devanear, a imaginar, a pensar. A criança não é imaginativa e criativa apenas por ser criança, ela tem a potência ${ }^{12}$ de aprender e não aprender modos de estar em linguagem na emergência de suas admirações no e com o mundo, de suas solidões, dos "tempos felizes em que o mundo causa admiração" (BACHELARD, 2009, p.76). Na fenomenologia bachelardiana, o devaneio não é desregrado, não estamos disponíveis para sonhar o que quer que seja pois os devaneios vinculam-se à familiaridade que as coisas sonhadas nos têm,

\begin{abstract}
fazem-se na concordância entre os nossos órgãos oníricos e o nosso coisário. Assim, nosso coisário nos é precioso, oniricamente precioso, pois nos oferece os benefícios dos devaneios ligados. Que prova de ser, reencontrar numa fidelidade de devaneio tanto o seu eu sonhador como o próprio objeto que acolhe o nosso devaneio. São ligações de existências que não poderíamos encontrar na meditação do sonho noturno. $\mathrm{O}$ cogito difuso do sonhador de devaneios recebe dos objetos de seu devaneio uma serena confirmação de sua existência (BACHELARD, 2009, p. 160).
\end{abstract}

Essa confirmação anima uma confiança existencial. Devaneios que lembram as admirações da infância, o cheiro da chuva que cai sobre a terra seca, o toque do barro na pele, sua força de resistência em nossa vontade de manipular e

\footnotetext{
12 Em Agamben (2006, p. 21), "a ambivalência específica de toda potência humana, que, na sua estrutura originária, se mantém relacionada com a própria privação, é sempre - e em relação à mesma coisa - potência de ser e de não ser, de fazer e de não fazer. [...] O ser vivo, que existe no modo da potência, pode a própria impotência, e apenas dessa forma possui a própria potência. Ele pode ser e fazer porque se mantém relacionado ao próprio não ser e não-fazer".
} 
transfigurar. O barro com sua resistência, a qual o corpo insiste com sua energia vital para transformar a massa em outra coisa na simultaneidade que também por ela é modificado, dinamiza imagens que não operam desde a visão apenas, pois a imaginação poética não é contemplativa. Pelo contrário, a imagem imaginada emerge do corpo-a-corpo com o mundo ao afrontar a resistência e as forças da materialidade, numa atitude sempre dinâmica e transformadora. Para Bachelard (1998, p. 165), a realidade só pode ser constituída quando a ação "é suficientemente ofensiva, inteligentemente ofensiva. Então todos os objetos do mundo recebem seu justo coeficiente de adversidade" (BACHELARD, 1998, p.165).

Neste sentido, a imaginação poética emerge do ato de insistir com a resistência que as materialidades oferecem à transformação da ação do corpo e, por isso, para Bachelard (2013, p.17), "nao há imagens sem excitação", sem provocação do mundo. Interrogamos, com o filósofo, “que seria uma resistência se não tivesse uma persistência, uma profundidade substancial, a profundidade mesma da matéria?" (BACHELARD, 2013, p. 17). A imaginação dinâmica nos faz viver uma adversidade provocada, no qual a matéria revela nossas forças, nosso coeficiente de ação no mundo, nosso esforço nos sucessos e fracassos. Assim, também o barro pode revelar a força transfigurativa da criança.

O mundo é tanto o espelho do nosso tempo quanto a reação das nossas forças. Se o mundo é a minha vontade, é também o meu adversário. Quanto maior a vontade, maior o adversário. O mundo é minha provocação. Compreendo o mundo porque o surpreendo com minhas forças incisivas, com minhas forças dirigidas, na exata hierarquia de minhas ofensas, como realizações de minha alegre cólera, de minha cólera sempre vitoriosa, sempre consquistadora (BACHELARD, 1998, p.165-66).

O devaneio, ao atualizar valores de ação no mundo, permanece em nós como um convite a habitar e participar do mundo com outras palavras. A palavra, para Bachelard (1993), é matéria que convém insistir em sua resitência para aprender a habitá-la. Não segundo qualquer livre fantasia, evaporação, vaporização ou fuga da realidade, mas a partir deste mergulho que ele nomeia devaneio ${ }^{13}$. O devaneio com

\footnotetext{
${ }^{13}$ No conjunto de sua obra, Bachelard distinguiu diversos tipos de devaneio: o devaneio poético, os devaneios materiais, o devaneio dinâmico, o devaneio cósmico, o devaneio operante, os devaneios da vontade, devaneios da infância. Diferentes devaneios que podem combinar-se, acrescentar-se e misturar-se. Bachelard passa seguidamente de um a outro pois todos promovem a abertura - ou estado de alma nascente -para uma feliz adesão ao mundo.
} 
palavras não é livre abandono a uma criação de ordem lingüística assim como não é atualização de fragmentos de uma autobiografia secreta. Para Burgos (1982, p.25), o devaneio em Bachelard "é inerente à linguagem mesma, inseparável de sua expressão ou de sua enunciação". O devaneio emerge intrinsecamente ligado à linguagem e esta não diz respeito à percepção ou à expressão anterior devolvida através de palavras, traços, sons, gestos: é a linguagem mesma que o devaneio ajuda a nascer, na qual ele se faz matriz (RICHTER, 2005) para o constituir como acontecimento de linguagem, portanto, acontecimento do corpo sensível, "acolhida" e apreendida como memória do corpo no mundo. A imaginação assume sua extensão ao instruir a linguagem a se ultrapassar.

É da experiência de linguagem que emerge o sentido da escrita - da pintura; do desenho. Escrevemos ou pintamos ou desenhamos para transformar e retificar o já pensado, para deixar de ser o que somos e perseguir o que podemos ser. Nos recriarmos na e pela experiência da linguagem é o que nos interessa. Para tanto, nos detemos no instante poético da emergência do devaneio, como fenômeno tomado em sua atualidade. Aqui, o passado não é relevante, o que conta é estar presente no minuto da imagem, no próprio êxtase da repercussão da sua novidade.

Nos devaneios dessa escrita revemos e recriamos nosso "universo ilustrado com as cores de infância" (BACHELARD, 2009, p.112). Devaneios que lembram os acontecimentos da primeira vez, o cheiro da chuva que cai sobre a terra seca, o toque do barro na pele. Com Bachelard (1997), consideramos a imaginação que emerge do corpo e acontece como linguagem. Assim o convite dessa escrita é superar uma concepção de imaginação reprodutora da aparência das imagens visuais. Nos fazeres com o barro podemos admirar a potência da imaginação poética como esforço do corpo na produção de sentidos que nos instalam no mundo e permanecem como valor. A admiração pelas imagens das crianças brincando com o barro permanece em nós como um princípio de vida relacionado à possibilidade de recomeçar (BACHELARD, 2009), como força que nos devolve o mundo como devaneio, que afirma a utilidade do inútil. A imaginação poética emerge então como força dinamizadora na constituição de reservas de entusiasmo que nos ajudam a 
acreditar e confiar no mundo para escrever e desvelar em nós o desconhecido. Um convite a habitar e participar do mundo com outras palavras na educação de crianças pequenas.

É preciso compartilhar um ponto final com palavras. Com devaneios ao escrever. Recorremos ao poeta Manoel de Barros (1999) para compor nossos silêncios e resgatarmos alguns exercícios de sermos pesquisadoras, professoras, para juntas devanearmos escrevendo. Aprendemos, com o poeta e com o filósofo, com devaneios e ideias, que a intencionalidade de aprender e saber algo de liberdade e de poesia exige compartilhar nosso devir adulto com as crianças, pois elas têm um modo de carregar água na peneira e de roubarem o vento para mostrar aos adultos os compossíveis, as coexistências possíveis dos fingimentos, das modelagens do ficcional. Compreendemos então que se aprendêssemos a escrever poderíamos também aprender a sonhar e a pensar de outros modos e, assim, poderíamos brincar com as palavras para mostrar que viver e escrever são uma e mesma experiência incontornável de fazer vir a ser o que somos. Poderíamos então aprender a continuar brincantes da e na linguagem para escrever e adentrar nos devaneios de uma infância. Com elas não há pressa, mas o exagero da desaceleração. Aqui, o lento não é o rápido freado. A lentidão é o demais, o excesso, "próprio timbre do imaginário" (BACHELARD, 2013, p. 22). Por incrível que pareça as crianças - como os poetas e os filósofos - são percebidas como esquisitas pelos seus exageros de infância.

\section{referências}

AGAMBEN, Giorgio. A potência do pensamento. Trad. de Carolina Pizzolo Torquato. Revista do Departamento de Psicologia. - UFF, v. 18 - n. 1, p. 11-28, Jan./Jun., 2006. Disponível em <http://www.scielo.br/pdf/rdpsi/v18n1/a02v18n1.pdf> Acesso março de 2012.

ARENDT, Hannah. A condição humana. Trad. Roberto Raposo; revisão técnica e apresentação Adrianao Correia. 12.ed. revisada. Rio de Janeiro: Forense Universitária, 2014.

ARENDT, Hannah. A vida do espírito - O pensar, o querer, o julgar. Trad. Antônio Abranches, César Augusto, Helena Martins, Rio de Janeiro: Civilização Brasileira, 2008. BACHELARD, Gaston. A água e os sonhos. São Paulo: Martins Fontes, 1998.

BACHELARD, Gaston. A formação do espírito científico: contribuição para uma psicanálise do conhecimento. Rio de Janeiro: Contraponto, 1996. 
BACHELARD, Gaston. Fragmentos de uma poética do fogo. Organização e notas Suzanne Bachelard. São Paulo: Brasiliense, 1990.

BACHELARD, Gaston. A poética do espaço. São Paulo: Martins Fontes, 1993.

BACHELARD, Gaston. A poética do devaneio. São Paulo: Martins Fontes, 2009.

BACHELARD, Gaston. A terra e os devaneios da vontade: ensaio sobre a imaginação das forças. São Paulo: Martins Fontes, 2013.

BARROS, Manoel de. Exercícios de ser criança. Rio de Janeiro: Salamandra, 1999.

BARROS, Manoel de. Escritos em verbal de ave. Biblioteca Manoel de Barros (coleção). São Paulo: LeYa, 2013.

BURGOS, Jean. Pour une poétique de l'imaginaire. Paris: Seuil, 1982.

GALEANO, Eduardo. O livro dos abraços. Porto Alegre: L\&PM, 2007.

FABRE, Michel. Bachelard éducateur. Paris: Presses Universitaires de France, 1995.

LEMINSKI, Paulo. Caprichos E Relachos. São Paulo. Editora brasiliense, 1983.

MERLEAU-PONTY, Maurice. Signos. Tradução Maria Ermantina Pereira.São Paulo, Martins Fontes, 1991.

NAKANO, Katsuko. Terra, Fogo, Homem. São Paulo: Aliança Cultural Brasil-Japão, 1989. RICHTER, Sandra Regina Simonis. A dimensão ficcional da arte na educação da infância. 2005. Tese (Programa de Pós-Graduação em Educação - Doutorado em Educação) Universidade Federal do Rio Grande do Sul, Porto Alegre, 2005.

ROMERO, Luis Puelles. La estética de Gaston Bachelard. Una filosofia de la imaginación creadora. Madrid: Verbum, 2002.

ROSA, João Guimarães. Grande Sertão: Veredas. Rio de Janeiro: Nova Fronteira, 2001. SERRES, Michel. Variações sobre o corpo. Rio de Janeiro: Bertrand Brasil, 2004.

SKLIAR, Carlos. Isto não é um livro de poemas. Rio de Janeiro: Texto Território, 2015.

recebido em: 19.10 .2016

aceito em: 20.11.2017 